\title{
THE PARADOX OF THE MORAL IRRELEVANCE OF THE GOVERNMENT AND THE LAW \\ A CRITIQUE OF CARLOS NINO'S APPROACH
}

JUAN CIANCIARDO ${ }^{1}$

\section{ABSTRACT}

Some authors have speculated about the fact that if the law were connected to moral, then it would not be relevant, because the moral would be enough to regulate social life. The study of this objection to the thesis of connection will be performed in this paper. In other words, the possible answers to the question about the practical difference that the law gives to the moral will be analyzed. Some papers written by the Argentine philosopher Carlos Nino will be the starting point for this task.

\section{KEYWORDS}

Human rights, argument of irrelevance, right and moral, democracy, government.

1 Researcher at Institute for Culture and Society, University of Navarra, Spain. E-mail: jcianciardo@unav.es. 
SUMMARY

THE PARADOX OF THE MORAL IRRELEVANCE OF THE GOVERNMENT AND THE LAW A CRITIQUE

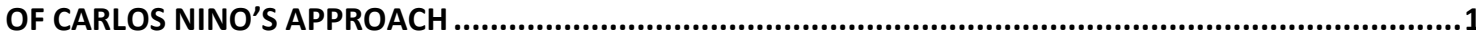

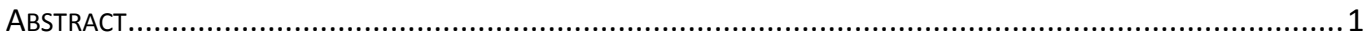

1. INTRODUCTION: NINO AND THE ARGUMENT OF THE PARADOX............................................................ 2

2. NINO'S PROPOSAL: ANALYSIS OF THE DEEPER ASSUMPTIONS ....................................................... 5

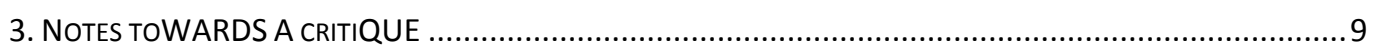

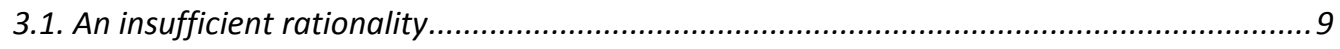

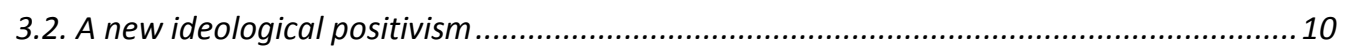

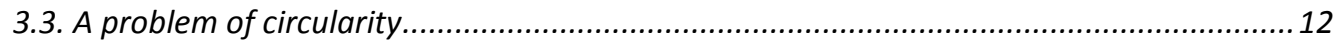

3.4. Guidelines for an alternative proposal............................................................... 13

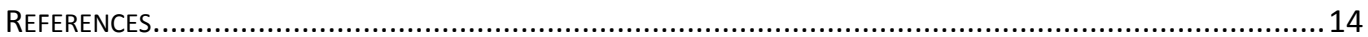

\section{INTRODUCTION: NINO AND THE ARGUMENT OF THE PARADOX}

According to Javier de Lucas, the ontological question about the law (what is the law?) should not be regarded as a starting point. In his opinion, only can it be considered the first question if the real initial question is overlooked. Paraphrasing Heidegger, the latter could be expressed by: why the law and not violence? De Lucas says that only from this point of view can we define the core around which the Philosophy of Law will spin ${ }^{2}$. It is only from this perspective that we will be able to understand the relationship between two facts of utmost importance, which are provided by Sociology and Juridical Science: the relationship between the law and the (social) human life, and the normative condition of the law, "which always tries to order the behavior of man" ${ }^{3}$. It is only from this viewpoint that we will be able to transcend the scientistic unidimensionalism in the search for an answer to a philosophical question ${ }^{4}$ : why the law rather than violence?

The next pages will indirectly deal with this fundamental topic. My objective is to contribute to solve it by means of analyzing a problem which is deeply connected to it. This may be summarized in the following question: why the law rather than Morals? In other

\footnotetext{
2 Javier DE LUCAS $(1982,121-125,122)$.

3 Ibidem.

${ }^{4}$ Vid. Pedro SERNA (2006, 127-141).
} 
words, what is the practical difference that the law brings to Morals? Among the very many existing paths, I will choose to base the development of the topic on the description of the "paradox of the irrelevance" and its corresponding solution, such as it was offered by the Argentinean philosopher Carlos Nino. Then, I will criticize this proposal and sketch the central lines of an alternative position, which is, in my opinion, better and more useful to ultimately answer the question posed in this paragraph ${ }^{5}$.

Nino referred to this topic on several occasions, two of which are worth mentioning: the article "La paradoja de la irrelevancia moral del gobierno y el valor epistemológico de la democracia", first published in $1986^{6}$; and the book Derecho, Moral y Política. Una revisión de la teoría general del Derecho, published in $1994^{7}$, after his death.

The Argentinean professor approached "the paradox" from two different perspectives. In the first paper mentioned above, the starting point Nino used was a question about the moral justification of democracy, "in the sense of the rule of the majority" ${ }^{\prime}$. Instead, in the second paper, the starting point was the analysis of the possible direct connection between Law and Politics ${ }^{9}$.

In this paper I will only deal with the first of the approaches above mentioned. According to Nino, two answers have been given to the question about the moral justification of democracy. There are some people who focus on the "intrinsic characteristics that the democratic decision-taking system seems to have, which would give it a moral value which cannot be found in other systems that do not possess such characteristics ${ }^{10}$. As an example of this type of argument, Nino proposes one according to which, democracy "enables the exercise of the popular sovereignty" and "ensures the consent of the governed about of the norms which are adopted by the rulers". A second group of answers aims at "the beneficial consequences that the democratic form of government brings about" ${ }^{\prime 11}$. As examples of this type of argument, Nino states that democracy: a) "increases the opportunities of the individuals to exercise their autonomy", b) "promotes self-respect and independent spirit", c) "ensures the satisfaction of the biggest number of preferences"12.

${ }^{5}$ About this expression, vid. Ángeles RódenAs, (1991, 279-293 y 1996, 226 ss.); Andrea GREPPI, (2008, 221-259). Raz had treated it (1991, 242, 155 y passim)

${ }^{6}$ Vid Carlos Nino (1986; 1989, 111-133; 1991, 36-51).

${ }^{7}$ Carlos Nino (1994, 130-160).

${ }^{8}$ NINO $(1989,113)$.

${ }^{9}$ NINO, (1994, 130).

${ }^{10}$ NINO, $(1989,113)$.

${ }^{11}$ Ibidem.

12 Idem, 114. 
According to Nino, these two types of argument are deficient. In the first case, because "either the properties which are taken into account are not genuine attributes of democracy, or because such properties materialize in such a way, that the fact that they really give value to democracy becomes doubtful" ${ }^{13}$. This is clearly seen as regards the argument of popular sovereignty: "unless we hypostatize the people as an entity which is different from the individuals who integrate it, democracy does not ensure that the will of the rulers will coincide with that of each of the governed"14. On the contrary, the second type of justifications provides reasons, although they are "relatively weak if they are not accompanied by another type of argument" ${ }^{\prime 15}$. First, such weakness comes from the type of justification which is aimed at because it depends on contingent circumstances and on an uncertain appraisal of the consequences, which "makes the value of democracy narrower than that which our intuition assumes" ${ }^{16}$. On the other hand, "the appraisal of the beneficial consequences of democracy is performed in an holistic manner, taking into account the benefit of society as a whole, which brings about problems of distribution, such as: why would the increase of the autonomy of the majority of the population, which is obtained through the democratic system, justify the possible restriction of the autonomy of the minority ${ }^{17}$.

In view of the problems of current justifications, Nino proposes a change in strategy: "maybe it would be more useful to inquire first about the justification of the existence of some sort of government, and then determine if that justification requires conditions that are only met by a democratic government" ${ }^{\prime 18}$. The approach he proposes is to deal with this matter as from the connected question about the obligatoriness of the juridical norms ${ }^{19}$. According to Nino, this is far from being a trivial question, so its answer must satisfy some conditions: "such obligatoriness comes from other norms whose obligatoriness does not depend on subsequent norms nor on the fact that they are obeyed or not ${ }^{\prime 20}$ because the former would lead to an ad infinitum reasoning and the latter to a fallacy. This type of obligatoriness is characteristic of moral principles. "In other words, when we inquire about the obligatoriness of juridical norms, we are inquiring about their moral obligatoriness, that is, about the moral principles which, under certain conditions to be defined, prescribe that some rules should be obeyed" ${ }^{21}$. This is

\footnotetext{
${ }^{13}$ Idem, 113.

${ }^{14}$ Ibidem.

${ }^{15}$ Idem, 114.

${ }^{16}$ Ibidem.

${ }^{17}$ Ibidem.

18 Ibidem.

${ }^{19}$ See ibidem.

${ }^{20}$ Idem, 115.

${ }^{21}$ Ibidem.
} 
connected to, according to Nino, the moral justification of the government which gives those (morally) obligatory norms: "the fact that a government is morally legitimate seems to be a good reason (which may be displaced by others) to make its rules obligatory (although there may be other reasons which justify the obligation to obey some rules of a morally illegitimate government) $)^{22}$.

In this point, the initial question about the justification of democracy may be rebuilt in the following way: "does the fact that juridical norms are originated in the democratic process make any difference?"23. While trying to answer this, Nino realizes that there is a paradox, which he believes to be apparent: "if, in order to decide whether to obey the juridical norms or not, we have to turn to moral principles which will determine if they are obligatory or not which is the same as saying if what they prescribe should be done or not- then, why are such juridical norms necessary?, why do we not simply focus on the moral principles which determine the behavior to be adopted?"24. The paradox appears because, at least apparently, "it is necessary to resort to moral principles for juridical norms to be operational, so that they provide or complete reasons for action; but as such principles indicate on their own how we should act, they make those juridical norms superfluous" 25 .

Once the problem has thus been stated, Nino will develop two possible answers which he will find unsatisfactory, and he will conclude with his own solution, which he will believe to be the best. In the following pages, I will focus on the Nino's proposal, and I will criticize them.

\section{NINO'S PROPOSAL: ANALYSIS OF THE DEEPER ASSUMPTIONS}

According to Nino, there are two meta-ethical assumptions which underlie the paradox argument. "The first one is that there is a moral system which is independent of the social practices involved in the constitution, recognition and exercise of the government, in such a manner that when the moral citizen resorts to such system to justify the government or its norms, he can reach conclusions as regards what he has to do, without taking such practices into account ${ }^{\prime 26}$. The second assumption refers to the epistemological scope, rather than the ontological one. From this point of view, it is possible to know the moral system in a manner independent of the social practices involved in the government and in the law. As we will see,

\footnotetext{
22 Ibidem.

${ }^{23}$ Ibidem.

${ }^{24}$ Ibidem.

${ }^{25}$ Idem, 115-116.

${ }^{26}$ Idem, 124-125.
} 
Nino will accept the existence of the first assumption, but he will reject the existence of the second one to reject the validity of the paradox of irrelevance.

In the first place, there is a position that states the inexistence of an independent moral order (and thus, it could be concluded that it would affirm the relevance of the government and the law, and the unsustainability of the paradox) which is called moral nihilism and which rejects the existence of a moral order in itself, regardless of the form in which it would be understood. Nino does not consider this position due to the fact that what originated the inquiry was precisely the search for moral reasons considered to be sound enough to justify the government and the law. In other words, the question in itself - regarding the moral reasons that justify the government and the law - implies that the law does not justify itself just because it is made up by a set of prescriptions or because it is efficient, on the one hand, or because of the unacceptability of moral nihilism, on the other hand.

In the second place, the social subjectivism also rejects the existence of an independent moral order, as the former believes that "saying that something is good is just as saying that the majority prefers it, or approves of $\mathrm{it}^{\text {"27 }}$. According to this line of thought, "the moral order would be built by means of exercising democracy" ${ }^{28}$. Thus, "the moral man would find no reasons which are independent of the norms of the government to justify such government, which would, consequently, make the norms of the government superfluous" ${ }^{29}$.

Just as Nino says, this position is unacceptable. From the viewpoint of the issue we are now dealing with, its key objection is that "due to its definition, it makes the position of the minority false, and thus, it cannot explain the moral progress (the result of the position of the minority becoming that of the majority), and it establishes the most absolute moral conservatism" ${ }^{30}$.

A third position which rejects the assumption of the existence of an independent moral order is that of Habermas's, which Nino defines as "a more complex and subtle variety of the ethical subjectivism of a social nature" ${ }^{31}$, "which is sometimes identified with a sort of ethical constructivism, and which maintains that moral reasons are built by means of the development of the moral discourse". According to this position, "valid moral principles are those which are attained through a discussion process which is limited by certain formal restrictions ${ }^{\prime \prime 32}$. If such discussion process were identified with that which develops in the heart

\footnotetext{
27 Ibidem.

${ }^{28}$ Idem, 126.

${ }^{29}$ Ibidem.

30 Ibidem.

${ }^{31}$ Ibidem.

32 Ibidem.
} 
of democracy, then not only would it justify the relevance of the government and the law, but it would lead to the conclusion that democracy is the only legitimate form of government. In other words, "we would come to the conclusion that democracy is the only form of government in which the latter is not superfluous for those who autonomously follow moral principles, as only democracy brings into the government the discussion through which morality is built" ${ }^{33}$.

The latter alternative is the most attractive for Nino, who discovers and develops the relationship between democracy and moral discourse. Nino proposes an "epistemological constructivism", which is based on the thought of Rawls and Habermas ${ }^{34}$. According to him, the moral discourse "is the social practice meant to obtain unanimous consensus on certain principles which could be used to ultimately justify actions and institutions". Although in many cases it is possible to obtain such consensus, in other cases it is impossible to do so because "there is a relevant moment to adopt the norm or course of action and if by such moment no unanimous consensus has been obtained, the discussion becomes ineffective 135 .

The solution to this problem is not to insist on achieving unanimous consensus, because doing so would imply favoring "the group which supports the statu quo so that no decision is adopted, although the group could be a minority" ${ }^{\prime 36}$. Consequently a new course of action should be searched for. Nino believes that the solution would be to settle a relevant time to take the decision and to replace the unanimous consensus for a simple majority, instead of a qualified majority which would give veto power to the minority ${ }^{37}$. From this point of view, democracy is "a succedaneum of the moral discourse": "it is a regulated form of discussion which has to be resorted to when a discussion leads nowhere". On the one hand, the moral discourse is a procedure of pure perfect procedural law because the criterion with which the result of its validity is assessed is having followed its rules, which - in turn - assures such validity. On the other hand, democracy is also a procedure of pure procedural law but it is imperfect because its rules imply drifting apart from the ideal procedure ${ }^{38}$.

If the first deep (that is, metaethical) assumption were false, the paradox of the irrelevance would be overcome. That is to say, if an independent moral order did not exist

33 Ibidem.

34 Idem, 93. Nino says that he will defend this approach "by contrasting the thought of two outstanding philosophers: John Rawls and Jürgen Habermas. However, I believe none of them correctly explains this position. As they miss the target by moving in opposite directions, the contrast between their positions (...) lets us infer the appropriate theoretical direction" (93).

${ }^{35}$ Idem, 127.

${ }^{36}$ Ibidem.

${ }^{37}$ See ibidem.

${ }^{38}$ Cfr. ibidem. 
(independent of democracy), then democracy and the laws would be relevant. However, according to Nino, the independent moral order somehow exists. The explanation of this conclusion is that in every moral discussion the topic being discussed is the legitimacy of the interest defended by those who discuss, and, in turn, the discussion about the legitimacy of the interest implies the existence of moral principles whose validity is independent of the results of such discussion ${ }^{39}$. From this viewpoint, "it cannot be denied that every moral discourse implicitly or explicitly alludes to moral principles or theories" ${ }^{\prime 4}$.

Because of this, a deep moral discussion should ultimately deal with which basic moral principles are valid ${ }^{41}$. The validity of a principle lies on its hypothetical acceptability by "all those who may be affected by this principle (no matter what their interests, life plans and personal characteristics are)" under certain conditions (full impartiality, rationality and knowledge $)^{42}$. Such being the case, the moral principles are not the result of real discussion. Instead, valid moral principles are the result of an ideal consensus which is alluded to in such real discussion ${ }^{43}$.

Based on this, Nino rejects what he calls "ontological constructivism", and he accepts an "epistemological constructivism". This leads him to accept, at least implicitly, the existence of an independent moral order, but not the existence of an independent moral knowledge (i. e., it is impossible to access to such moral order in an individual and isolated manner, that is, independent of any social practice ${ }^{44}$ ). He gives epistemological value to democracy "as an adequate method to acquire moral knowledge, as the former essentially includes the discussion and agreement of the majority, which are ways to approach moral truth" ${ }^{\prime 5}$. It is worth mentioning that in the first stages of his thinking, Nino had chosen an "ontological constructivism" ${ }^{\prime 46}$.

By means of discarding the assumption of independent moral knowledge, the Argentinean author believes that he has also rebutted the argument of the paradox. He says: "opposing to what we supposed at the beginning, the second assumption is partially false as a general hypothesis and its inexistence makes the existence of the government relevant as far as it is democratic: the moral man usually wants to act according to moral reasons even if he is

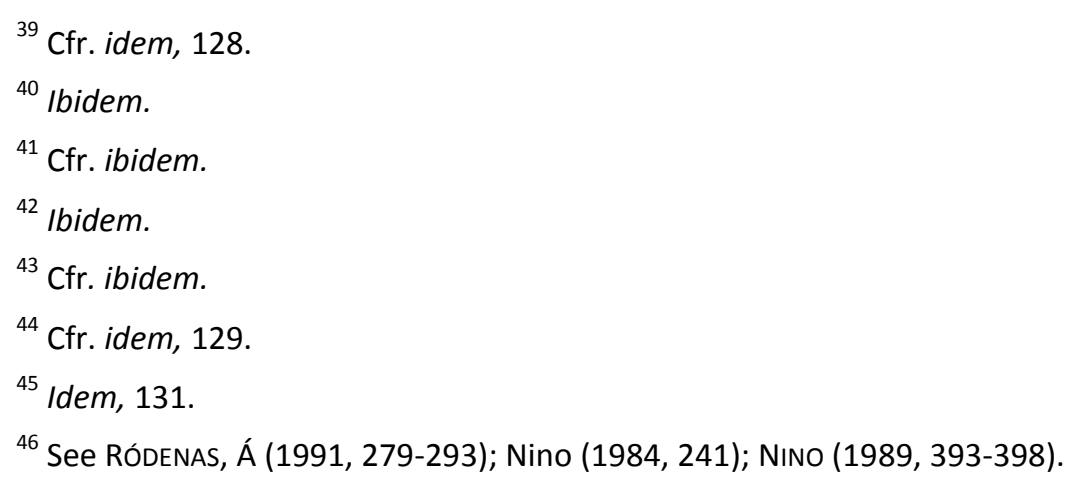


not sure which such reasons are. The process of democratic discussion, which is reflected in the decisions made by the democratic authorities, can guide the moral man towards valid moral principles" ${ }^{\prime \prime 7}$. On the other hand, the law is relevant because it is succedaneum of the moral discourse. On the contrary, a non democratic government - and its laws - would not allow the moral man to access a valid moral order, and in this sense, the argument of irrelevancy would not be affected.

\section{NOTES TOWARDS A CRITIQUE}

Once Nino's description of the paradox has been made, and the different options that he analyzed and discarded together with his answer have been presented, it is time to point out same critiques.

\subsection{AN INSUFFICIENT RATIONALITY}

From Nino's viewpoint, the inexistence of the independent moral knowledge is an argument to rebut the paradox if the government, democracy and norms are efficient means to develop the moral discourse. If this were not so, the paradox would be valid, and it would be necessary to find another way to invalidate it.

The basic problem is that Nino's constructivism fails. Let's see why. He tries to build a proposal that would overcome dogmatism and skepticism without leaving ethical objectivity aside ${ }^{48}$. This is important for him because "it is impossible to offer moral solutions to normative problems without $\mathrm{it}^{\prime \prime 4}$. Such problems are those which are basic for the participants of a juridical practice, that is, judges and citizens. However, Nino will be dogmatic and skeptical. What happens is that his proposal is incapable of achieving a strong, that is, true ethical objectivity. The reason for this failure is that Nino's moral is an artifact created by man, just a technique, a construct. The rationality of such moral, its justification, should be, consequently, a rationality which comes from the core of the moral itself, capable of providing internal coherence completion or logical-formal correction, though not truth. Nino's reason is

${ }^{47}$ NINO, C. (1989, 131-132).

${ }^{48}$ Nino is one of the very many authors who are driven by a concern which has been identified key to understand contemporary Philosophy of Law: "the search for a certain kind of ethical-legal objectivity, without the need to resort to cognitive, and thus veritable, conception of Ethics (...)" (MASSINI, C. I., 2004, 8).

${ }^{49}$ BLANCO, S. (2002, 145). 
internal, and as such, it is not useful to offer the justification for the practice itself which we call moral, which is not possible to be found by resorting to its ends or to the rationality itself of the moral performance" ${ }^{\prime \prime 0}$.

As regards dogmatism, Nino points out that democracy is, above all, a procedure (similar to the moral discourse) to learn moral principles. On the other hand, as regards skepticism, the Argentine author highlights a normative nature of democracy. Democracy, both procedure and rule, lacks sufficient justification and it is ultimately stated rather than justified in the discourse. In fact, "the justification of the discursive moral practice according to its ends and functions proposed by Nino only postpones the problem, because the discursive moral practice supposes, in the first place, to identify such ends and functions, and in the second place, to consider such ends and functions valuable" ${ }^{\prime 51}$. That is why, at the end, Nino's justification of Moral "is achieved by means of the somewhat dogmatic assumption of a certain conception of man, which is supposed to be backed up by a sociological verification. This voluntaristic selection of the ends of the Moral is also what determines its consideration mainly as an intersubjective phenomenon" ${ }^{25}$.

Although Nino realizes that a justification of the normative nature of democracy cannot be performed from a viewpoint that will reduce it to pure procedure, he only progresses half way (as Kaufmann has written, from procedure and form it is impossible to obtain anything but procedure and form). Overcoming this critique implies having some knowledge of what man is and of what is good for him, that is to say, an anthropology and an ethic become imperative. In Nino's case, the problem is that he designs "a juridical Moral which (...) is built in the image and after the likeness of democracy. Instead of giving value to democracy as a succedaneum of the moral discourse, this author creates a moral which, because it includes the characteristics of democracy, leads to the defense of democracy as a morally acceptable form of government whose norms must always be obeyed by all the citizens" ${ }^{\prime 23}$.

\subsection{A NEW IDEOLOGICAL POSITIVISM}

My second critique consists in rejecting the practical difference between ontological and epistemological constructivism. Nino's thinking evolved from the former (ontological constructivism) to the latter (epistemological constructivism), which he considered to be more

\footnotetext{
50 Ibidem.

${ }^{51}$ Idem, 148.

52 Idem, 149.

${ }^{53}$ Idem, 150.
} 
advantageous. However, from the point of view which is offered by the argument of the paradox, the differences seem to disappear.

According to Nino, democracy is not the same as the moral discourse (because if this were so, Nino would be an ontological constructivist). In contrast, democracy is a succedaneum of the moral discourse, which leads to the possibility for the norms produced by democracy not to be morally valid. At this point, there are two problems to be solved. On the one hand, if democracy is a succedaneum of the moral discourse, then it is necessary to explain how it is possible to know if the democratic norms are valid or not. On the other hand, if such democratic norms are morally invalid, then it is necessary to decide what to do.

As it is very difficult for Nino to find an answer to the first problem, he concludes that "except in case of error, in democratic countries it may be compulsory to act according to the juridical system" ${ }^{54}$. As regards the second problem, and as a consequence of the former, "from a practical point of view, Nino demands that this probability becomes a certainty when putting it into practice. According to the principle which states that the possibility to act in a morally correct manner should be maximized, Nino believes that the democratic discourse, even if it is imperfect, justifies and even demands to disregard one's own opinion and to obey the norm" ${ }^{\prime 55}$.

From this point of view, juridical norms are "exclusionary reasons" according to Raz ${ }^{56}$, although Nino does not define them in this way. He believes that juridical norms actually are epistemic reasons. That is to say, they are reasons to believe that there are reasons for action. In this way, he wants to preserve the autonomy of the moral, which he believes would be questioned if there were practical authorities, and also to escape from ideological positivism (which would happen if the norms were directly defined as exclusionary reasons) and, simultaneously, to state the enforcement of the positive law ${ }^{57}$.

In turn this answer faces two difficulties. The first one is that "if we believe that within epistemological constructivism democratic norms become exclusionary reasons, autonomy, which is an assumption of the moral discourse, is at risk, because the receivers of the juridical norms will always overlook their own moral judgment because they will adopt the norm as the only possible guideline. On the contrary, if we believe, such as Nino did, that they are a epistemic reasons (...) when it is stated that an individual has reached through his own reflection the conviction that there are relevant moral mistakes in democratic norms, and at the same time he is supposed to believe «in the existence of moral reasons which favor this

\footnotetext{
54 Idem, 151.

${ }^{55}$ Idem, 152.

${ }^{56}$ See RAz, J. (1999; 1986, chap. 3; 2004; 2006).

${ }^{57}$ NiNO, C. $(1989,152)$.
} 
norms", we are in fact demanding him to accept two different criteria of correction simultaneously, without offering any definite reason to choose one or the other ${ }^{\prime 58}$.

Consequently, such as Blanco stated, Nino's proposal ultimately has a certain resemblance with ideological positivism, although he was looking for the opposite result $t^{59}$.

\subsection{A PROBLEM OF CIRCULARITY}

According to Nino, as shown above, the practical difference that the norms provide would come from the fact that they are an expression of democracy, which is a succedaneum of the moral discourse. This way the existence of democratic (and not of any other of type of) government would be justified.

If we go back, we will remember that Nino connects the answer to the paradox with three problems: the justification of democracy (this is, in fact, his starting point), the justification of the government, and the justification of the law. If we analyze Nino's approach the other way round, we will see that it involves trying to find out what practical difference the law will provide, so that the government can be justified and, depending on the type of practical difference we find, democracy may be justified.

This leads to a third critique. If the practical difference of democracy can be perceived by studying the difference which is brought about by the existence of the government and, in turn, if the practical difference of the government requires the study of the relevance of the law, then it does not seem to be logical to explain the importance of the law by resorting to democracy. It is insufficient to argue that Nino is only referring to one aspect of democracy. If only democracy justifies democracy, then its justification is impossible. We are only able to describe it, thus it is impossible to limit it ${ }^{60}$. A more adequate response to this serious problem demands to base our reasoning on a richer anthropological description which will not consider autonomy and rationality absolute values ${ }^{61}$.

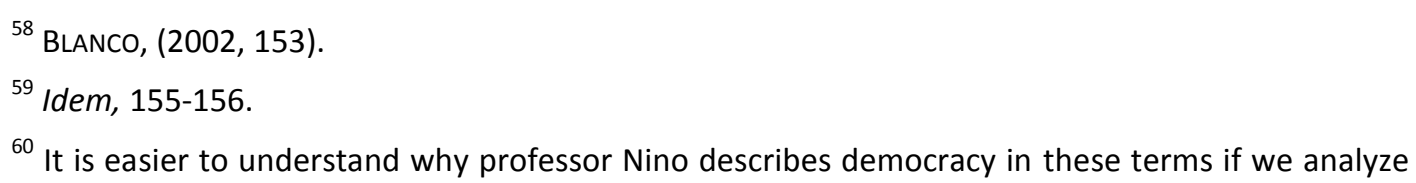
his biography, through which we will learn that he played an outstanding role in the development of Argentine democracy immediately after the military dictatorship that the country suffered between 1976-1983. See Blanco (2002, 262-315) and Jorge Malem SeÑA, (2008, 281-357). See, too, the preliminary study of Owen Fiss in Gustavo MAURINO (2007, 11-17).

The impact of such context is even clearer if we analize the topics Nino became interested in, as from 1984 (for example in 1984, 1985, 1992, 1992 -b-).

${ }^{61}$ See Pedro RIVAS (2004, 1-33). 


\subsection{GUIDELINES FOR AN ALTERNATIVE PROPOSAL}

Why law and not only the moral? If that were so, would any moral do? Why the government instead of anarchy? Why democracy and not any other type of government? What are the limits of democracy? Who to balance what is political and what is juridical? All of these belong to a group of relevant questions which underlie many political and social conflicts of the beginning of this century.

The classical tradition brings forth an interesting line of thinking, which I will only sketch here, which is based on Aristotle: man is the only political creature. Such statement can be interpreted as follows: the human being can only fulfill himself in the polis, in society; it is only in this context where he can obtain the necessary means to reach the ends he tends to. The polis is autarchic (as opposed to the family and other communities) because it has the capacity to produce these means ${ }^{62}$. For this reason, the polis is also a way of basic coexistence ${ }^{63}$.

As within the polis, men coexist, there are social relations that call for coordination and adopting criteria that would solve the conflicts that might arise. This role cannot be completely played by the moral due to several reasons: first, because there are people who are not willing to abide by moral rules; and second, because the moral is inconclusive and indeterminate. To overcome these deficiencies there are two elements which are necessary: on the one hand, an authority which will guide the polis towards autarchy (the common good) and, on the other hand, the law which punishes some immoralities (not all) and concludes and determines all the aspects relevant to the common good which are not solved by the moral ${ }^{64}$.

At least as a hypothesis, it seems it would be possible to accept the violent imposition of the moral on those who are not willing to obey it, the violent resolution of coordination problems and conflicts, and the violent settlement of those aspects of the moral which the moral neither concludes nor determines. However, morality itself prescribes the acknowledgement of the other man as equal. Men acknowledge man as an end in himself,

\footnotetext{
62 See ARISTÓTELES (2005, 7-47).

${ }^{63}$ See a development of this idea in Sergio CotTA (1985, passim).

${ }^{64}$ See Carlos MASSINI (1999, 91-103).
}

What is stated above is the starting point of one of the existent arguments to support the connection between law and moral. The moral requires conclusion and determination, and at the same time, it guides the decisions of the legal practitioners in those cases in which the juridical system does not provide a univocal solution. In my opinion, based on this, it is possible to argue in favor of the connection thesis, even if the Dworkinian thesis of the only right answer were upheld. See Ronald DWORKIN (1978). Also see Carlos MASsINI (2006), and Gabriel Mora ReStRePo (2009, 137-153), and Pilar ZAMBRANO (2009). 
which demands respect and banishes any instrumentalization ${ }^{65}$. For this reason, the Moral prescribes that the solution to conflicts and the solutions to problems of coordination should be enforced without violence, respecting the demand for recognition. Neoconstitutionalism has coined the idea of reasonableness to describe those norms which could be considered juridical because they comply with the requisite mentioned above. A solution is reasonable if it is possible to justify it through attractive reasons. That is to say, it is a solution which is capable of arousing rational consensus. It is possible to argue that the best way to find such reasons is to search for them within the democratic dialogue. The democratic deliberation assures an important minimum of respect: every man should be considered a valid social partner or interlocutor.

The need to create reasonable norms that punish some immoralities (those which seriously affect the common good); that coordinate behaviors and solve social conflicts; and that conclude and determine what the moral norms do not conclude or determine, justifies the need for a government, and that such government should be democratic. Both a government and democracy are demanded by the common good. Politics and moral (due to its being inconclusive and indeterminate) demand a way of coexistence (the law) which calls for a government. And the government must be democratic because only democracy (by treating the other one as another one) can provide those norms which are reasons for action entrusted with authority (although it may achieved in different degrees or even it may not achieved because its actions are never perfect). Democracy is not a succedaneum of moral discourse. In fact, it is a demand of the moral discourse, which will always be, especially as regards the relations with others, inconclusive and indeterminate.

\section{REFERENCES}

ARISTÓteles. 2005. Política, Introducción, traducción y notas de María Isabel Santa Cruz y María Inés Crespo, Buenos Aires, Ediciones Losada (Colección Griegos y Latinos).

BLANCO, S. 2002. Positivismo metodológico y racionalidad política. Una interpretación de la teoría jurídica de Carlos S. Nino, Granada, Comares.

COTTA, S. 1985, Il diritto nell'esistenza: Linee di ontofenomenologia giuridica, Giufreé, Milano.

DE LUCAS, J. 1982. “La pregunta fundamental. Una precisión metodológica”, en Persona y Derecho 9.

DWORKIN, R. 1978. Taking Rights seriously, London, Duckworth.

${ }^{65}$ KANT, I. (1980, chap. 2). 
GreppI, A., 2008. "Consenso e imparcialidad. Sobre la justificación moral de la democracia en el pensamiento de C. S. Nino", in Carlos Rosenkratz and Rodolfo VIGo (comps.), Razonamiento jurídico, ciencia del derecho y democracia en Carlos S. Nino, México, Fontamara, 221-259.

KANT, I. 1980. Fundamentación de la metafísica de las costumbres. Translated by M. García Morente, Madrid, Espasa-Calpe.

Malem SeÑA, J. 2008. "In memoriam: Carlos Santiago Nino. Apuntes bio-bibliográficos", in ROSENKRATZ y VIGo (comps.), Razonamiento jurídico, ciencia del derecho y democracia en Carlos $S$. Nino (...), op. cit., 281-357.

MASSINI, C. 1999. "Iusnaturalismo, liberalismo, comunitarismo y la exigibilidad jurídica de las normas morales", in, by the same author, El Derecho natural y sus dimensiones actuales, Buenos Aires, Ábaco, 91-103.

MASSINI, C. 2006. "Dworkin, Finnis y "la única respuesta correcta»", in Santiago LEGARRE, Alejandro Miranda, Cristóbal ORREgo (eds.), La lucha por el derecho natural. Actas de las Jornadas de homenaje a John Finnis. A 25 años de la publicación de Natural Law and Natural Rights, Universidad de Los Andes, Santiago.

MASSINI, C. 2006. "Dworkin, Finnis y «la única respuesta correcta»", en Santiago LEGARRE, Alejandro MirAndA, Cristóbal ORREgo (eds.), La lucha por el derecho natural. Actas de las Jornadas de homenaje a John Finnis. A 25 años de la publicación de Natural Law and Natural Rights, Universidad de Los Andes, Santiago.

MASSINI, C. I. 2004. Constructivismo ético y justicia procedimental en John Rawls, México, UNAM.

Maurino, Gustavo (ed.). 2007. Derecho, Moral y Política. I. Metaética, ética normativa y teoría jurídica, Buenos, Gedisa.

MoRA RestREPO, Gabriel. 2009. Justicia constitucional y arbitrariedad de los jueces. Teoría de la legitimidad en la argumentación de las sentencias constitucionales, Buenos Aires-Madrid-Barcelona, Marcial Pons.

NINO, "La paradoja de la irrelevancia moral del gobierno y el valor epistemológico de la democracia", Análisis Filosófico VI-1 (1986).

Nino, C. 1984. Ética y derechos humanos, Buenos Aires, Paidós.

Nino, C. 1985. La validez del Derecho, Buenos Aires, Astrea.

Nino, C. 1989. El constructivismo ético, Madrid, Centro de Estudios Constitucionales.

Nino, C. 1989. Ética y derechos humanos. Un ensayo de fundamentación, Buenos Aires, Astrea.

Nino, C. 1991. "The Epistemological Moral Relevance of Democracy", Ratio luris 4, nro. 1, 36-51.

Nino, C. 1992. Fundamentos de derecho constitucional. Análisis filosófico, jurídico y politológico de la práctica constitucional, Buenos Aires, Astrea. 
Nino, C. 1992 -b-. Un país al margen de la ley. Estudio de la anomia como componente del subdesarrollo argentino, Buenos Aires, Emecé Editores.

Nino, C. 1994. Derecho, Moral y Política. Una revisión de la teoría general del Derecho, Barcelona, Ariel.

RAZ, J, 1999. Practical Reason and Norms, Oxford University Press.

RAZ, J. 1979. The Authority of Law. Essays on Law and Morality, Oxford, Clarendon Press,

RAZ, J. 1986. The morality of Freedom, Clarendon Paperbacks, Oxford University Press, New York.

RAZ, J. 2001. "Reasoning with Rules", Current Legal Problems, 54.

RAZ, J. 2004. "Incorporation by Law", Legal Theory, 10.

RAZ, J. 2006. "The Problem of Authority. Revisiting the Service Conception", Minnesota Law Review, 90.

RIVAS, P. 2004 Las ironías de la sociedad liberal, México, UNAM.

RódenAS, Á., 1991. "Sobre la justificación de la democracia en la obra de Carlos S. Nino", en Doxa: Cuadernos de Filosofía del Derecho 10, 279-293.

SERNA, P. 2006. Filosofía del Derecho y paradigmas epistemológicos. De la crisis del positivismo a las teorías de la argumentación jurídica y sus problemas, México, Porrúa.

ZAMBRANO, P. 2009. La inevitable creatividad en la interpretación jurídica. Una aproximación iusfilosófica a la tesis de la discrecionalidad, México, UNAM. 